\title{
OBITUARY
}

\section{S. RACHEL SHPAN-GABRIELITH}

(1906-1991)

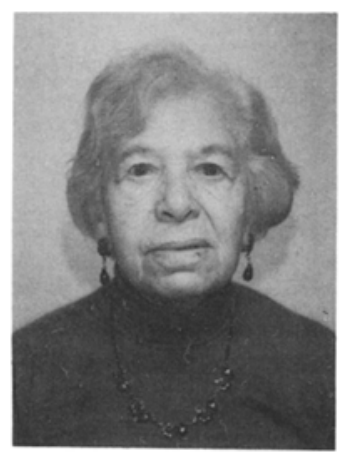

IN MEMORIAM

Dr. S. Rachel Shpan-Gabrielith, a former entomologist at the Ministry of Agriculture, died on August 5, 1991. She was born on June 7, 1906, within the walls of the old city of Jerusalem - a seventh generation in Old Jerusalem - where she attended elementary school at 'Kol Israel Chaverim'; later she studied at and graduated from high school at the Hebrew Gymnasium in Jerusalem. She continued her studies at the Levinsky Seminar for teachers in Tel Aviv and graduated in 1924. From 1924 to 1926 she served as a teacher at the Education Center in Kefar Gil'adi, Galilee. From 1927 until 1930 she worked in the Forestry Division of the Department of Agriculture of the then British Mandatory Government. Subsequently she studied at the University of Florence in Italy, receiving her doctoral degree at graduation, with specialization in Entomology.

Dr. Shpan-Gabrielith returned to Israel in 1934 and was appointed Plant Inspector in the Department of Agriculture of the British Mandatory Government. From 1940 until 1945 she was employed as tutor to external students from London University in courses of Botany and Zoology. In 1945 she was appointed Head of the Entomology Collection at the Ha'Aretz Museum, Tel Aviv, and served in that capacity until 1948.

In October 1948 Dr. Shpan-Gabrielith commenced her work as chief entomologist in the Plant Protection Division of the newly formed Israeli Ministry of Agriculture (this Division was the predecessor of the present Department of Plant Protection and Inspection [DPPI] of the Ministry). Her main emphasis was on research on plant pests, especially fruit flies and the desert locust. She also established the rearing laboratory of these insects. 
In $1960 \mathrm{Dr}$. Shpan-Gabrielith attended and lectured at the International Entomological Congress in Vienna, Austria. Following the Congress she visited laboratories specializing in Biological Control in various countries, including France.

During the last decade of her work, Dr. Shpan-Gabrielith investigated a quarantine insect, Myiopardalis pardalina (Bigot) (Baluchistan melon fly). She also established an excellent scientific library in the DPPI, which was of much help to the workers there as well as at other scientific institutions.

In 1964-65 Dr. Shpan-Gabrielith was awarded an F.A.O. fellowship for study at the Anti-Locust Research Centre in London. Her main research subject there was repellents for desert locust control. In 1968 she visited the U.S.S.R. and Iran within the framework of her studies of the Baluchistan melon fly. She retired from Government Service on March 31, 1972 .

She was a very experienced and well known research worker in the field of Entomology in Israel as well as abroad, especially in the subject of locust research. On singling out one of the prominent scientific achievements of Dr. Shpan-Gabrielith, her studies of plants with phagodeterrent properties for the desert locust [information taken from Proc. 3rd Int. Neem Conf., pp. 45-53 (1987)], initiated with her work on Persian lilac, Melia azedarach, come to mind. She remembered from early childhood a Persian lilac tree in the courtyard of her home in the old city of Jerusalem. Since her father was a pharmacist, familiar with the Latin names of trees and plants, she already knew as a child the name Melia azedarach, called then in the vernacular 'Mai-reslech' (May roses), because the tree blossoms in Jerusalem in May.

In 1915, during World War I, there was a very heavy invasion of the desert locust, Schistocerca gregaria (Forsk.), into Palestine, which is vividly described in the book Jerusalem by Sven Hedin (1918). Further, Whiting reported in 1915 from Jerusalem that vineyards, and fig, apricot, quince and pomegranate trees were completely defoliated, fields of tomato, cucumber, melon, watermelon and durra, etc., were left completely bare, and later neither palms nor olive trees were spared. The only plants not attacked were Persian lilac and oleander. The well-known zoologist Aharoni stated in 1916 that only Persian lilac and, to a lesser extent, carob trees, Egyptian sycamore and Ricinus, the castor-oil plant, were spared. It was Aharoni who showed Rachel Gabrielith in 1922, when she was a high-school pupil catching insects for him, a classic photograph taken during the locust invasion of 1915. It depicted an orchard with all its leaves devoured by the locust, except for one tree which retained all its leaves: Melia azedarach. While working on the locust in the Department of Agriculture during the British Mandate before World War II, Dr. Shpan-Gabrielith initiated a research project on the palatability of plants to $S$. gregaria, classifying them as palatable, partly palatable, and barely acceptable or unpalatable. Among the barely acceptable plants, she found some which were structurally suited to live in arid places (xerophytes), especially species growing in salt marshes or near the sea (halophytes), such as Anabasis, Anthrocnemum, Bassia and Chenolea, as well as some other genera having tender leaves, such as the Judas tree or Cercis, and Acacia. She uncovered very interesting feeding relationships according to the state of the leaf. For instance, Nerium oleander is rejected by the desert locust. Its leaves contain the cardiotonic and diuretic oleandrin or neriolin, as well as nerin, a further cardiotonic substance found also in the sea onion, Urginea maritima. Adult desert locusts were found to nibble only the midrib of Nerium leaves, whereas they fed partially on $U$. maritima, after its leaves had withered; similar observations were made with another bulbous plant, Pancratium maritimum. Asphodelus microcarpus (Liliaceae) was accepted readily when cut into pieces, whereas undamaged leaves connected to a water supply were rejected. Freshly cut Euphorbia, variously called milk weed, wolf's milk, or spurge, from which latex exuded, was found to be repellent, whereas the leaves of the undamaged plant were accepted readily. On the basis of such extensive and specialized experience, Dr. Shpan- 
Gabrielith was impressed that the only plant species which remained completely untouched by locust in this test, even after 7 or 8 days of starvation, was $M$. azedarach, from which she concluded already in the 1940 s that it must contain a very potent phagorepellent for the desert locust. Similarly, among the hot-water extracts obtained from leaves of all the test plants, and applied to wheat bran, only the $M$. azedarach extract prevented feeding completely. The same results were obtained with sucrose-treated filter papers which, when offered to fifth midstadium hoppers starved for $24 \mathrm{~h}$, were devoured voraciously, but were not touched if treated with the $M$. azedarach extract. These findings were put by her to good use a few years later when, in 1951, Israel suffered a locust invasion through the traditional gateway of the Red Sea. The first settlement in the path of the locust was Kibbutz Yotvata, near Elat. The newly established tomato fields in the kibbutz had to be protected urgently from the invading locusts. Dr. Shpan-Gabrielith's recipe, based on extract batches of $0.5 \mathrm{~kg}$ of Persian lilac leaves boiled in 10 liters of water and then diluted, was used to spray the plants and, as a result, the locust shunned the tomato fields of Yotvata. This encouraged her to send to all locust-threatened villages and kibbutzim a box with various stages of $S$. gregaria, so that the farmers would recognize the locust when it appeared; a sample of Persian lilac leaves; as well as precise instructions how to prepare the extract of the leaves of the tree, which is ubiquitous in Israel.

In 1964, during her fellowship at the Anti-Locust Centre in London, she worked with locust-repellent plants and repellent exudations from plants, and found basil, Ocimum basilicum (Labiatae), to be strongly repellent to locust. She also studied all the Melia species growing in the Royal Botanic Garden in Kew and prepared extracts from leaves, fruit pulp and seed kernels; the highest activity was found in the leaves.

Later in the same decade Dr. Shpan-Gabrielith cooperated with Prof. David Lavie and his team of chemists at the Weizmann Institute of Science at Rehovot, Israel, on locating and identifying phagorepellent materials in both fresh fruits from Persian lilac, and seed oil from Indian lilac, or neem, Azadirachta indica. Locust antifeedant sucrose-filter paper assays conducted by Dr. Shpan-Gabrielith steered the chemists towards the active fraction and finally to the locust phagorepellent meliantriol, discovered in 1967.

It is obvious that Rachel Shpan-Gabrielith was one of the outstanding pioneers in the field of insect phagodeterrents.

Rachel Shpan-Gabrielith was married to the late eminent teacher, writer and translator, Dr. Shlomo Shpan; he passed away in 1962. Dr. Shpan-Gabrielith was known as an anonymous donor of funds to families in need; she continued this generous activity also after the death of her husband.

Dr. Shpan-Gabrielith was a very fine person as well as co-worker. All her colleagues, as well as those who knew her socially, will remember her as such and will miss her.

S. Elhanan

Ch. Chen

Z. Klein

K.R.S. Ascher

Inst. of Plant Protection

$A R O$, The Volcani Center

Dept. of Plant Protection and Inspection

Bet Dagan 50250, Israel

Ministry of Agriculture

Bet Dagan 50250, Israel 